\title{
Membangun Tata Kelola Klinis Melalui Clinical Pathway Demam Berdarah Dengue Rumah Sakit Umum Rizki Amalia Medika
}

\section{Enuk Endah Sunarto*}

*Penulis Korespondensi: ndah_humairo@yahoo.co.id

Magister Manajemen Rumah Sakit Universitas Muhammadiyah Yogyakarta

\begin{tabular}{l}
\hline $\boldsymbol{I} \boldsymbol{N} \boldsymbol{D} \boldsymbol{E} \boldsymbol{X I N} \boldsymbol{G}$ \\
\hline Keywords: \\
clinical governance, \\
clinical pathway, dengue \\
haemorrhagic fever
\end{tabular}

\begin{abstract}
A B S T R A C T
In Rizki Amalia Medika Hospital there are variations in the treatment of patients with dengue haemorrhagic fever, so that it is requires better governance. This study is purposed to develop a clinical pathway of dengue haemorrhagic fever and to formulate clinical governance which are required to develop in Rizki Amalia Medika Hospital. This study is a qualitative research in Rizki Amalia Medika Hospital from September to November 2014. The data were obtained from medical records, standards of medical services and hospital reports, and interviews. The data analysis was performed with qualitative data analysis techniques. This research resulted in clinical pathways dengue fever based on the agreement of medical and paramedical staff in Rizki Amalia Medika Hospital, which is a template containing the information : a) the name of the patient, No. RM, date of birth, and special notes, b) information services every day for 6 days, c) variations in service with a date, reason and signature, d) the date of entry and exit, and e) the main diagnosis and the concomitant, accompanied ICD 10 code. Clinical pathway of dengue fever was used as the basis of examination and medical care of patients. This experiment also produced clinical governance which should be built in Rizki Amalia Medika Hospital among others: clinical audit activity, evidence-based clinical practice, and continuing education for medical staff. Clinical governance is necessary to achieve an appropriate health care standards.
\end{abstract}

Article history: received 12 April 2016; revised 22 Mei 2016; accepted 17 Juni 2016

\section{PENDAHULUAN}

Rumah sakit adalah lembaga yang memberikan pelayanan klinik sehingga mutu klinik merupakan indikator penting bagi baik buruknya rumah sakit. Rumah sakit membutuhkan suatu sistem yang dapat meningkatkan mutu pelayanan klinik dengan cara memadukan pendekatan manajemen, organisasi dan klinik secara bersama-sama. Sistem ini disebut tata kelola klinis. Tata kelola klinis adalah suatu upaya dalam peningkatan mutu pelayanan dan menjamin kualitas pelayanan dengan membangun lingkungan pelayanan klinis yang baik dalam suatu organisasi penyelenggara pelayanan kesehatan ${ }^{1}$.

Salah satu sistem yang diterapkan dalam tata kelola klinis adalah clinical effectiveness. Dengan clinical effectiveness suatu penyelenggara pelayanan kesehatan menjamin memberikan pelayanan terbaik yang berbasis bukti secara efektif. Clinical effectiveness dapat dilakukan antara lain dengan penyusunan clinical pathway ${ }^{2}$.

Clinical pathway di rumah sakit merupakan pedoman yang mencakup semua aktivitas dari pasien masuk hingga keluar rumah sakit. Pedoman ini berguna untuk meningkatkan mutu pelayanan dan pengendalian biaya pelayanan. Clinical pathway dapat digunakan sebagai alat evaluasi untuk pelayanan medik yang bermutu dan untuk menghindari tindakan atau aktivitas yang tidak diperlukan ${ }^{1}$. Hal ini merupakan pedoman dasar perhitungan biaya pelayanan sehingga pasien mendapatkan kepastian biaya dari upaya penyembuhan penyakitnya ${ }^{3}$.

Berdasarkan data yang diperoleh dari rekam medis RSU Rizki Amalia Medika terdapat banyak variasi dalam penatalaksanaan pasien demam berdarah dengue, baik itu variasi penggunaan obat maupun variasi pemeriksaan penunjang. Sehubungan dengan hal tersebut penulis akan melakukan penelitian dengan 
judul "Membangun tata kelola klinis yang baik melalui penyusunan clinical pathway demam berdarah dengue di RSU Rizki Amalia Medika."

\section{METODE PENELITIAN}

Jenis penelitian yang dilakukan adalah penelitian kualitatif. Penelitian ini dilakukan di RSU Rizki Amalia Medika pada bulan September sampai dengan November 2014. Semua data rekam medis pasien demam berdarah dengue di RSU Rizki Amalia Medika periode januari-desember 2013 ada sebanyak 49 pasien. Sampel penelitian ini adalah semua data rekam medis pasien demam berdarah dengue dengan usia saat dirawat lebih dari 19 tahun di RSU Rizki Amalia Medika bulan januari-desember 2013. Data diperoleh dari data rekam medik, standar pelayanan medis rumah sakit dan laporan rumah sakit. Tujuan pengambilan data adalah untuk melihat variasi perawatan pasien dan memperkirakan rata-rata lama rawat inap (avarege length of stay/ALOS) serta tindakan yang diterima pasien hari perhari selama dirawat.
Data dalam penelitian ini diperoleh dari rekam medik, standar pelayanan medis dan laporan rumah sakit, serta diskusi kelompok terarah dan wawancara.

Instrumen untuk mengumpulkan data dalam penelitian ini adalah: (1) Daftar isian data rekam medis, (2) Daftar isian data penatalaksanaan pasien, dan (3) SPM demam berdarah dengue RSU Rizki Amalia Medika. Analisis data yang digunakan adalah analisis kualitatif meliputi: pengumpulan data, reduksi data, penyajian data dan kesimpulan. Analisis ini dilakukan secara hati-hati dan berkelanjutan agar diperoleh gambaran dan simpulan yang sebaikbaiknya.Tahap-tahap penelitian: (1) Mengumpulkan data rekam medik pasien demam berdarah dengue periode rawat inap bulan Januari - Desember 2013. (2)

Menganalisis rekam medik pasien demam berdarah dengue. (3) Wawancara dengan dokter spesialis penyakit dalam dan kepala ruang untuk menyusun clinical pathway. (4) Wawancara mendalam dengan ketua komite medik. Secara skematis tahaptahap penelitian di atas dapat digambarkan sebagai berikut:

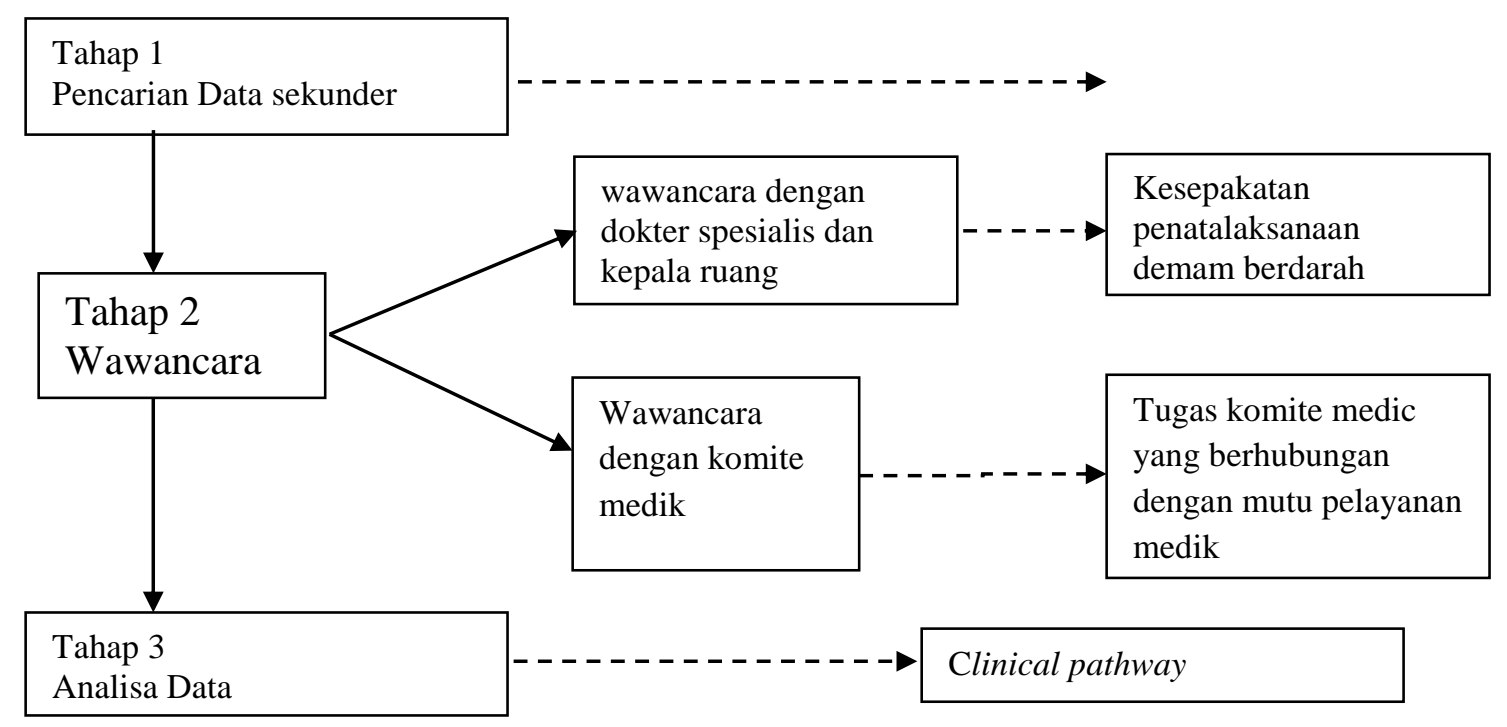

Keterangan gambar :

$\rightarrow \quad$ Tahap yang dilakukan

$\rightarrow \quad$ Hasil yang diperoleh

Bagan 1 Tahap Penelitian 


\section{HASIL DAN PEMBAHASAN}

\section{Gambaran umum}

RSU Rizki Amalia Medika adalah rumah sakit yang sudah berdiri sejak tahun 2002. Awal RSU Rizki Amalia Medika adalah sebuah RSKB (Rumah Sakit Khusus Bedah) yang kemudian berubah menjadi Rumah sakit umum tahun 2012.

\section{Staf medis}

RSU Rizki Amalia Medika memiliki 8 orang dokter umum dan 1 dokter gigi dengan 4 diantaranya adalah dokter tetap. Selain itu juga memiliki beberapa dokter spesialis yaitu spesialis penyakit dalam, spesialis bedah, spesialis anak, spesialis obsgin, spesialis radiologi, spesialis saraf, spesialis anastesi dan spesialis ortopedi. Dari 8 dokter spesialis tersebut tidak ada yang dokter tetap karena semua adalah PNS. Tiap dokter spesialis hanya hadir di rumah sakit sesuai jadwal praktek mereka. Masing-masing dokter spesialis memiliki jadwal praktek poli sebanyak 2 kali dalam seminggu. Jika ada pasien yang perlu dikonsulkan ke dokter spesialis di luar jadwal praktek maka dokter jaga akan melakukan konsultasi via telepon. Jika ada pasien dokter spesialis yang rawat inap maka dokter jaga akan melaporkan perkembangan pasien setiap hari kepada dokter spesialis yang bersangkutan via telepon, kecuali dokter spesialis penyakit dalam yang selalu melakukan visite pasien rawat inap setiap hari kerja walaupun di luar jadwal prakteknya.

\section{Komite Medik}

Guna menjaga kualitas pelayanan dan tata kelola klinis yang baik di RSU Rizki Amalia Medika, direksi membentuk komite medik. Komite medik dikepalai oleh seorang dokter umum. Komite medik memiliki 2 staf medis fungsional (SMF) yaitu SMF bedah dan SMF non bedah. Jumlah SMF yang hanya 2 menurut ketua komite medic dikarenakan jumlah dokter di tiap spesialisasi hanya satu orang dokter sehingga mereka digabung dan dibedakan menjadi bedah dan non bedah. SMF bedah terdiri dari dokter spesialis bedah, dokter spesialis ortopedi, dokter spesialis obsgin, dan dokter gigi. SMF non bedah terdiri dari dokter spesialis penyakit dalam, dokter spesialis anak, dokter spesialis radiologi, dokter spesialis saraf, dokter spesialis anastesi dan dokter umum.

Komite medik di RSU Rizki AMalia Medika belum memiliki sub komite seperti yang diatur dalam PMK no. 755 tentang komite medik ${ }^{4}$. Hal ini dikarenakan sibuknya para dokter spesialis dan kurangnya sumber daya. Fungsi komite medik yang sudah berjalan selama ini di RSU Rizki Amalia Medika:

\section{Fungsi kredensial}

Penerimaan tenaga dokter di RSU Rizki Amalia Medika hanya memperhatikan apakah dokter tersebut punya STR atau tidak, dan apakah bersedia untuk praktek di RSU Rizki Amalia Medika. Jika syarat itu terpenuhi maka mereka langsung dipersilahkan praktek di RSU Rizki Amalia Medika. Untuk dokter umum tidak ada keharusan memiliki sertifikat ATLS/ACLS/GELS yang masih berlaku walaupun pihak komite medik paham bahwa itu sangat penting namun dikarenakan susahnya mencari tenaga medis yang bersedia bergabung di rumah sakit maka syarat itu tidak menjadi mutlak.

\section{Fungsi mempertahankan kompetensi dan} profesionalisme staf medis

Pendidikan berkelanjutan bagi para dokter baik berupa pelatihan, symposium, workshop maupun seminar tidak dikelola dan ditata dengan baik oleh komite medik, semua diserahkan kepada para dokter untuk melaksanakan sesuai keinginan para dokter tersebut tanpa memperhatikan kebutuhan rumah sakit. Hal ini dikarenakan cepatnya perputaran dokter terutama dokter umum. Menurut ketua komite medik saat ini mereka sedang mempersiapkan pelatihan yang diadakan oleh rumah sakit seperti hasil wawancara yaitu “...Kami sedang merencanakan untk melakukan program pelatihan.... “

Komite medik belum pernah melakukan audit medis maupun audit kematian di rumah sakit dikarenakan kesibukan para dokter spesialis. 
Fungsi menjaga disiplin, etika dan perilaku profesi staf medis

Fungsi ini berjalan ketika ada kasus etika yang terjadi di rumah sakit. Tidak ada pertemuan khusus untuk sosialisasi mengenai etika dan disiplin profesi kedokteran baik itu yang dilakukan berkala oleh komite medik maupun saat orientasi tenaga dokter. Komite medik selama ini berfungsi hanya menjaga agar pelayanan oleh dokter kepada pasien tetap berjalan dengan baik. Program kerja komite medik juga tidak tertuang dengan jelas. Jadwal pertemuan komite medik dibuat setahun sekali mengingat kesibukan para dokter spesialis tersebut, bahkan karena terlalu sibuk sehingga jadwal pertemuan yang setahun sekali itupun sering tidak terpenuhi. Dalam menjaga clinical governance yang baik selain melalui peran komite medis, rumah sakit juga melibatkan pasien yaitu dalam bentuk menyiapkan kotak saran di kawasan rumah sakit dan juga adanya penilaian kepuasan pasien tiap tahun.
Jumlah pasien dengan diagnose DHF dari januari desember 2013 berjumlah 49. Sebelas pasien berusia kurang dari 19 tahun saat dirawat, empat pasien pulang atas keinginan sendiri, dua pasien dirujuk, dan 13 pasien memiliki diagnose bukan demam berdarah dengue. Sehingga total ada 19 pasien. Dari 19 pasien yang diambil menjadi sampel ada 10 karena hanya untuk melihat pola pelayanan pasien demam berdarah dengue. (1) Lama hari rawat pasien demam berdarah dengue adalah 6 hari (2) Penggunaan obat.Penggunaan obat masih bervariasi, antara lain penggunaan obat selain antipiretik, penggunaan obat amoxilin yang sebenarnya adalah antibiotic, dan penggunaan imunos yang fungsinya untuk meningkatkan daya tahan tubuh 3. Pemeriksaan penunjang

Pemeriksaan penunjang juga bervariasi tidak hanya angka trombosit,

angka leukosit dan hematokrit, namun masih juga ada pemeriksaan widal

\section{Hasil pengambilan data dari rekam medis}

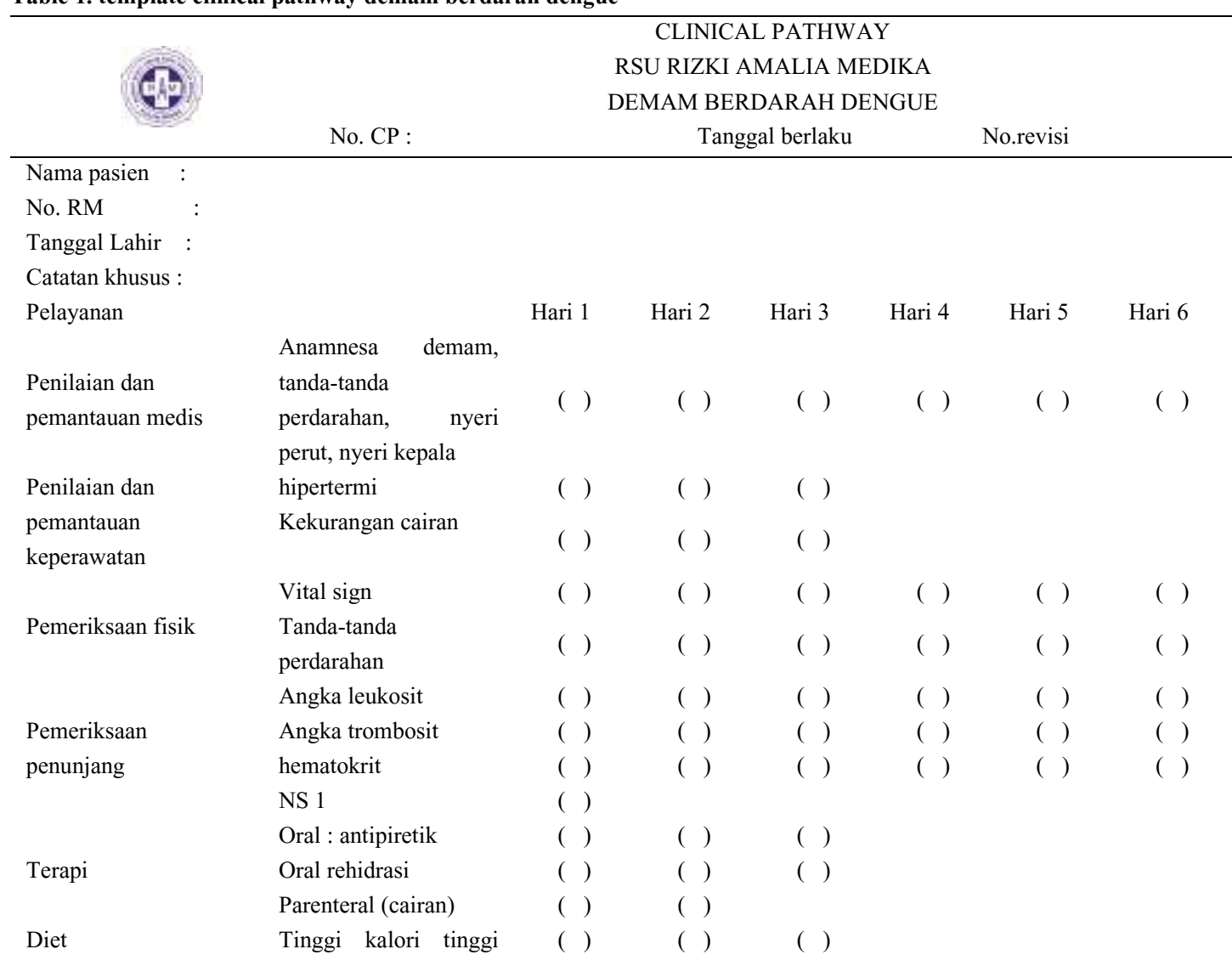




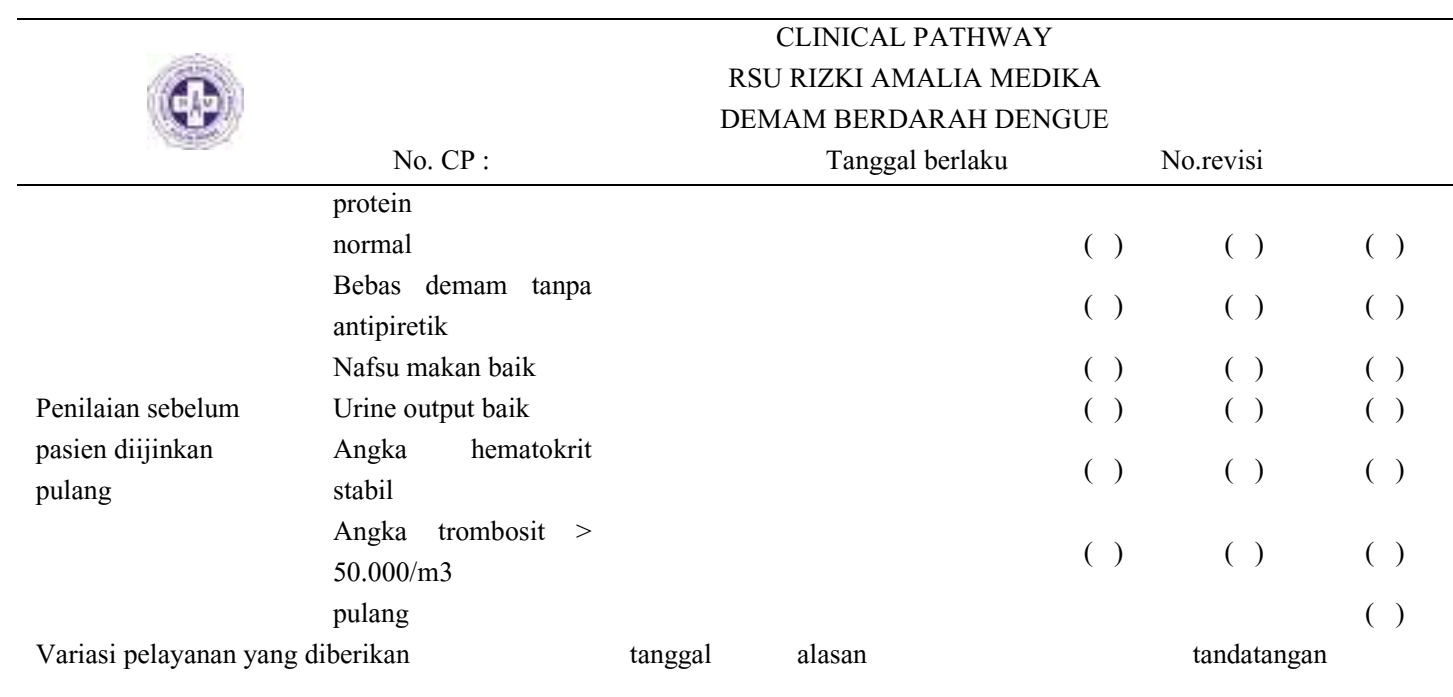

\begin{tabular}{ll} 
Tanggal masuk & Tanggal keluar \\
Diagnose utama & Kode ICD 10 \\
Diagnose penyerta & Kode ICD 10 \\
\hline
\end{tabular}

Dari clinical pathway di atas dapat diterangkan sebagai berikut: Tanda-tanda / pengertian DHF. Tanda-tanda/gejala DHF adalah: (a) panas tibatiba selama 2-7 hari dengan disertai dua atau lebih gejala nyeri kepala, nyeri retro-orbital, myalgia/atralgia, rash, leukopenia (b)Munculnya satu atau lebih tanda-tanda perdarahan, yaitu: (Tes tourniquet positif, Ptekie, echimosis, atau purpura, Perdarahan mukosa (biasanya epistaksis atau perdarahan gusi)
- $\quad$ Haematemesis atau melena

(c) Trombositopeni ( angka trombosit $<100.000$ / mm3 )

(d) Adanya bukti kebocoran plasma yang ditandai satu atau lebih gejala berikut: ( Haematokrit meningkat $>20 \%$ berdasarkan usia dan jenis kelamin, Penurunan haematokrit $>20 \%$ setelah terapi cairan, Tanda kebocoran plasma (efusi pleura, ascites atau hipoproteinemia)).

Table 2. tanda dan derajat demam berdarah dengue

\begin{tabular}{|c|c|c|c|}
\hline DF/DHF & Grade & Simptom & Laboratorium \\
\hline DF & & $\begin{array}{l}\text { Demamdengandisertaiduatandaberikut: } \\
\text { nyerikepala, nyeri retro-orbita, mialgia, } \\
\text { atralgia }\end{array}$ & $\begin{array}{l}\text { Leucopenia, trombositopenia, } \\
\text { tidakadatandakebocoran plasma }\end{array}$ \\
\hline DHF & I & $\begin{array}{l}\text { Tanda-tanda di atasditambah test } \\
\text { tourniquet positif }\end{array}$ & $\begin{array}{l}\text { Trombositopenia }<100.000, \\
\text { peningkatanhematokrit } \geq 20 \%\end{array}$ \\
\hline DHF & II & $\begin{array}{l}\text { Tanda-tanda di } \\
\text { atasdisertaiperdarahanspontan }\end{array}$ & $\begin{array}{l}\text { Trombositopenia }<100.000, \\
\text { peningkatanhematokrit } \geq 20 \%\end{array}$ \\
\hline DHF & III & $\begin{array}{l}\text { Tanda-tanda di atasdisertaitanda- } \\
\text { tandakegagalansirkulasi (pulsasilemah, } \\
\text { hipotensi, lemah) }\end{array}$ & $\begin{array}{l}\text { Trombositopenia }<100.000, \\
\text { peningkatanhematokrit }>20 \%\end{array}$ \\
\hline DHF & IV & Shok & $\begin{array}{l}\text { Trombositopenia }<100.000, \\
\text { peningkatanhematokrit }>20 \%\end{array}$ \\
\hline
\end{tabular}


(e) Kriteria rawat inap pasien $\mathrm{DHF}^{5}$

- $\quad$ Pasien DF dan DHF grade I tidak perlu mondok. Namun dengan pengawasan keluarga selama di rumah sampai 2-3 hari bebas demam.

- Pasien DHF grade I dapat dipondokkan jika :

- terdapat tanda-tanda kebocoran plasma yaitu adanya peningkatan hematokrit 20\% (Laki-laki dengan hematokrit di atas $47 \%$, Wanita dengan hematokrit di atas $40 \%$ ) atau

- tidak ada keluarga yang dapat mengawasi kondisi pasien

- jarak rumah jauh dari rumah sakit

- pasien dipondokkan pada DHF grade II, III, IV

(f) Kriteria memulangkan

- Bebas demam setelah 4 x 24 jam tanpa penggunaan antipiretik

- Nafsu makan membaik

- Adanya perbaikan klinis

- Urine output yang baik

- Angka hematokrit yang stabil

- Tidak adanya respiratory distress

- $\quad$ Angka trombosit $>50.000 / \mathrm{mm} 3$

\section{Hari 1}

1. Anamnesa

2. Pemeriksaan

-Vital sign

-Pemeriksaan fisik

-Laboratorium : angka leukosit, angka trombosit, hematokrit,

3. Diet : nasi/bubur tinggi kalori tinggi protein

4. Oral rehidrasi direkomendasikan pada pasien dehidrasi sedang akibat muntah dan demam tinggi yaitu pada dewasa sebanyak 2,5-4 liter perhari

5. Pemasangan IV line dan pemberian larutan kristaloid jika terdapat peningkatan hematokrit > 20\%. Inisial IV therapy $6 \mathrm{ml} / \mathrm{kgbb} / \mathrm{jam}$ selama $3 \mathrm{jam}$. Cek ulang hematokrit/vital sign/ urine output setelah 3 jam. Jika terjadi perbaikan turunkan IV therapy menjadi $3 \mathrm{ml} / \mathrm{kgbb} / \mathrm{jam}$ selama $3 \mathrm{jam}$. Cek ulang hematokrit/vital sign/ urine output setelah 3 jam. Jika terjadi perbaikan lanjutkan pemberian terapy cairan $3 \mathrm{ml} / \mathrm{kgbb} / \mathrm{jam}$ selama 6-12 jam lalu hentikan pemberian terapi cairan. Jika tidak ada perbaikan tingkatkan pemberian terapi cairan $10 \mathrm{ml} / \mathrm{kgbb} / \mathrm{jam}$ selama sehari. Jika ada perbaikan turunkan terapi cairan dari $10 \mathrm{ml} / \mathrm{kgbb} / \mathrm{jam}$ menjadi $6 \mathrm{ml} / \mathrm{kgbb} / \mathrm{jam}$ lalu turunkan lagi menjadi $3 \mathrm{ml} / \mathrm{kgbb} / \mathrm{jam}$.

6. Pemberian obat simptomatis

- Jika masih dalam fase demam diberikan parasetamol maksimal 4 x $500 \mathrm{mg}$ perhari.

- Tidak perlu pemberian antibiotik

\section{Hari 2}

1. Anamnesa

2. Pemeriksaan

- Vital sign

- Pemeriksaan fisik

- Laboratorium : angka trombosit, hematokrit,

3. Diet : nasi/bubur tinggi kalori tinggi protein

4. Oral rehidrasi diteruskan

5. Melanjutkan pemberian IV therapy jika pasien hari 1 belum terdapat perbaikan hematokrit/vital sign/urine out put.

6. Pemberian obat simptomatis

- Jika masih dalam fase demam diberikan parasetamol maksimal 4 x $500 \mathrm{mg}$ perhari.

- $\quad$ Tidak perlu pemberian antibiotik

Hari 3

1. Anamnesa

2. Pemeriksaan

- Vital sign

- Pemeriksaan fisik

- Laboratorium : angka trombosit, hematokrit,

3. Diet : nasi/bubur tinggi kalori tinggi protein

4. Oral rehidrasi diteruskan. 
5. Pemberian obat simptomatis

- Jika masih dalam fase demam diberikan parasetamol maksimal 4 x $500 \mathrm{mg}$ perhari.

\section{Hari 4}

1. Anamnesa

2. Pemeriksaan fisik

3. Pemeriksaan laboratorium : angka trombosit, hematokrit

4. Diet normal

5. Tidak dibutuhkan tindakan dan pemberian obat apapun

\section{Hari 5}

1. Anamnesa

2. Pemeriksaan fisik

3. Pemeriksaan laboratorium : angka trombosit, hematokrit

4. Diet normal

5. Tidak dibutuhkan tindakan dan pemberian obat apapun

\section{Hari 6}

1. Anamnesa

2. Pemeriksaan fisik

3. Pemeriksaan laboratorium : angka trombosit, hematokrit

4. Diet normal

5. Tidak dibutuhkan tindakan pemberian obat apapun

\section{Pembahasan}

\section{Staf medis}

RSU Rizki Amalia Medika memiliki 8 (delapan) orang tenaga dokter spesialis paruh waktu. Dengan tidak dimilikinya dokter spesialis penuh waktu maka setiap dokter spesialis tidak setiap hari ada di rumah sakit untuk memberikan pelayanan kepada pasien ini dapat menurunkan kualitas pelayanan kepada pasien. Dokter spesialis tidak mengikuti perkembangan pasien secara langsung hanya mengandalkan laporan dari dokter jaga. Dan beberapa pasien pulang harus menunggu visite dari dokter penanggung jawabnya sehingga memperpanjang hari rawat.

Komite medik yang merupakan wadah non struktural bagi staf dokter di RSU Rizki Amalia Medika belum berjalan dengan baik. Ini akan mempengaruhi kualitas staf medis. Salah satu fungsi komite medik adalah kredensialing staf medis. Dengan tidak adanya kredentialing yang baik maka hanya akan mendapatkan staf medis yang belum tentu sesuai dengan kebutuhan rumah sakit. Kredensialing berfungsi untuk memastikan bahwa staf medis yang akan melakukan pelayanan medis di rumah sakit tersebut adalah kredibel ${ }^{4}$.

RSU Rizki Amalia Medika memiliki dokter spesialis bedah dan dokter spesialis ortopedi. Ini sangat perlu dibuatkan kewenangan klinis yang tegas berdasarkan hasil kredensialing agar tidak ada konflik kepentingan. Kejelasan ini sangat penting untuk mendukung kinerja dokter agar mampu memberikan layanan optimal. Kualitas layanan merupakan dasar dari layanan kesehatan ${ }^{6}$.

\section{Pendidikan berkelnjutan bagi staf medis}

Komite medik tidak melakukan fungsi peningkatan kompetensi dengan baik. Hal ini dapat menjadikan tingkat kompetensi yang tidak berkembang dari tenaga dokter terutama dokter umum. Hal ini bisa mengurangi mutu pelayanan klinis.

Pasien mempunyai harapan yang sangat tinggi bahwa dokternya memiliki pengetahuan dan keterampilan yang baik. Selain itu pasien juga mengharapkan dokternya memberikan standar pelayanan kesehatan terbaik ${ }^{7}$. Oleh karena itu rumah sakit diharapkan dapat menjaga kemampuan staf medisnya agar sesuai dengan harapan pasien.

\section{Audit Klinis}

Audit klinis merupakan hal yang sangat penting untuk dilakukan karena dengan audit klinis kita bisa mengetahui apakah kita sudah memberikan pelayanan kepada pasien dengan baik dan disesuaikan dengan standar yang sudah ada atau kesepakatan standar yang digunakan di rumah sakit ${ }^{8}$.

\section{Effektifitas klinis}

Lama hari rawat

Jumlah hari pada clinical pathway sama dengan hasil perhitungan lama hari rawat pada data dari RS 
yaitu 6 hari dikarenakan berdasarkan panduan dari WHO (1997) bahwa masa kritis adalah selama 2-3 hari dan masa pemulihan selama 2-3 hari dimana masa pemulihan juga membutuhkan observasi di rumah sakit sehingga ditotal menjadi 6 hari ${ }^{5}$.

Penggunaan obat

Data dari RS didapatkan bahwa banyak pasien diberikan cholescor yang isinya beras merah (angkak) yang dimaksudkan untuk mempercepat peningkatan angka trombosit. Banyak penelitian di Indonesia mengenai manfaat angkak terhadap peningkatan trombosit. Dari penelitian diperoleh bahwa terjadi peningkatan angka trombosit pada tikus putih yang diberi angkak dibanding dengan grup control ${ }^{9}$. Penelitian ini masih menggunakan tikus sebagai hewan coba belum ada percobaan yang besar yang dilakukan ke manusia. Penelitian yang banyak mengenai angkak ini adalah mengenai pengaruh angkak terhadap penurunan cholesterol. Oleh karena itu Regimen ini tidak dimasukkan dalam clinical pathway.

Pada penelitian pasien anak-anak dengan DSS yang diberi transfuse trombosit dibandingkan dengan pasien anak-anak dengan DSS yang tidak diberikan transfuse trombosit didapatkan bahwa tidak ada perbedaan yang bermakna dalam memperbaiki kondisi perdarahan, dan lama hari rawat dan kejadian edem pulmonal lebih tinggi pada grup yang diberi transfuse trombosit ${ }^{10}$. Oleh karena itu transfusi trombosit juga tidak dimasukkan dalam clinical pathway.

Pemeriksaan penunjang

Penggunaan clinical pathway dapat meningkatkan efisiensi pemeriksaan penunjang. Dengan menggunakan clinical pathway pemeriksaan penunjang yang dilakukan hanyalah pemeriksaan angka trombosit, angka leukosit dan hematokrit.

Pemeriksaan NS1 dimasukkan dalam clinical pathway karena penentuan diagnosis dalam clinical pathway ini menggunakan kriteria WHO 1997 dimana kriteria ini memiliki sensitivitas 95,4\% namun spesifisitasnya 36,0\% sehingga perlu dibantu dengan NS1 yang memiliki sensitifitas $80,5 \%$ dan spesifisitas $100 \%{ }^{11}$.
Berdasarkan gambaran di atas, penggunaan clinical pathway telah dapat mendorong terwujudnya tata kelola yang lebih baik sehingga dapat meningkatkan efisiensi dan efektivitas layanan kesehatan di RSU Rizki Amalia Medika. Dengan demikian tata kelola klinis di RSU Rizki Amalia Medika dapat berjalan dengan lebih baik, yaitu tata kelola klinis yang dapat memastikan bahwa sistem untuk memonitor kualitas praktek klinis yang berfungsi dengan baik, memastikan praktek klinis selalu dievaluasi dan hasil evaluasinya digunakan untuk melakukan perbaikan, serta memastikan praktek klinis sudah sesuai dengan standar yang dikeluarkan oleh badan regulasi profesi nasional. Tata kelola yang lebih baik di atas perlu didukung kompetensi dan profesionalisme staf medis. Kompetensi dan profesionalisme staf medis ini penting untuk menjaga agar layanan diberikan sesuai dengan standar. Selain itu, tata kelola yang baik juga perlu didukung oleh pelaksanaan audit klinis secara berkala. Hal ini dapat mendorong staf medis melakukan pelayanan terhadap pasien sesuai dengan standar serta meningkatkan efisiensi layanan.

Berdasarkan data dan pembahasan di atas dapat simpulkan bahwa tata kelola yang perlu dibangun di RSU Rizky Amalia Medika antara lain menyangkut: kegiatan audit klinis, efektivitas klinis, dan pendidikan berkelanjutan bagi staf medis. Audit klinis perlu dilakukan secara berkala, praktek klinik berbasis bukti melalui penggunaan clinical partway sebagai mekanisme penetapan standar layanan dan pijakan dalam pemeriksaan, serta pendidikan bagi staf medis yang dilakukan secara berkelanjutan sehingga mampu mendorong peningkatan kualitas layanan dan kinerja rumah sakit.

\section{SIMPULAN}

Berdasarkan data dan pembahasan dari penelitian ini dapat disimpulkan sebagai berikut. (1) Clinical pathway demam berdarah dengue berdasarkan hasil kesepakatan staf medis dan paramedis di RSU Rizki Amalia Medika adalah suatu template yang memuat informasi tentang: (2) No CP, tanggal berlaku, dan nomor revisi (3) Nama pasien, No. RM, tanggal lahir, dan catatan khusus (4) Informasi pelayanan tiap hari selama 6 hari, meliputi: penilaian dan pemantauan 
medis, penilaian dan pemantauan keperawatan, pemeriksaan penunjang, terapi, diet, dan penilaian sebelum pasien diijinkan pulang. (a) Variasi pelayanan yang diberikan, disertai dengan tanggal, alasan dan tanda tangan (b) Tanggal masuk dan tanggal keluas (c) Diagnose utama dan diagnose penyerta, disertai dengan Kode ICD 10. (5) Tata kelola klinis yang baik yang perlu dibangun di RSU Rizki Amalia Medika antara lain menyangkut: kegiatan audit klinis, efektivitas klinis, dan pendidikan berkelanjutan bagi staf medis. (a) Audit klinis perlu dilakukan secara berkala. Dengan dilakukannya audit klinis secara berkala mendorong staf medis melakukan pelayanan terhadap pasien sesuai standar serta dapat meningkatkan efisiensi karena staf medis akan cenderung melakukan tindakan dan pengobatan sesuai yang diperlukan oleh pasien. (b) Efektivitas Klinis. Efektivitas klinis dapat dilakukan melalui pengunaan clinical pathway . Penggunaan clinical pathway demam berdarah dapat mendorong terwujdunya tata kelola klinis yang lebih baik sehingga dapat meningkatkan efisiensi dan efektivitas layanan kesehatan di RSU Rizki Amalia Medika berupa: lama hari rawat

selama 6 hari, penyeragamkan penggunaan obat, dan peningkatan efisiensi pemeriksaan penunjang. (c) Pendidikan berkelanjuitan bagi staf medis. Pendidikan berkelanjuitan bagi staf medis perlu dilakukan untuk mendorong peningkatan kompetensi dan profesionalisme staf medis

sehingga dapat memberikan layanan yang sesuai dengan standar medis. Pendidikan berkelanjuitan bagi staf medis perlu dilakukan untuk mendorong peningkatan kompetensi dan profesionalisme staf medis.

\section{DAFTAR PUSTAKA}

1. Sale Diana, 2005, Understanding clinical governance and quality assurance making it happen, New York, Palgrave macmillan.

2. Middleton S., \& Robert A., 2000, Integrated Care Pathways: A Practical Approach to Implementation, Oxford , Butterworth Heinemann.

3. Queensland Government, 2005, A Toolkit for Developing a Clinical Pathway, Pathways and
Processes Team Clinical Practice Improvement Centre, Queensland.

4. Peraturan Menteri Kesehatan Republik Indonesia Nomor 755 Tahun 2011, Penyelenggaraan Komite Medik di Rumah Sakit, 11 April 2011, Jakarta.

5. World Health Organization (WHO). 1997. Dengue Haemorrhagic Fever Diagnosis, Treatment, Prevention and Control 2nd edition. Geneva.

6. Clinical Governance Committee, 2007, Clinical Governance Strategy For West Sussex PCT 2006 -2009 .

7. Wright J., Hill P., 2003, Clinical governance, Churchill Livingstone, Toronto.

8. Department of Health Government of Western Australia, 2005a, Introduction to Clinical Governance - A Background Paper, Information Series 1.1, Office of Safety and Quality in Health Care, Western Australia.

9. Indah S., Wigati K. W., Wardani T., 2013, Comparing The Effect of Red Yeast Rice, Date Palm, and Guava Leaf Extract on Thrombocyte and Megakaryocyte Count in Thrombocytopenic White Rats, Folia Medica Indonesiana 49 (2) : 82-87.

10. Kurukularatne C., et al, 2011, When Less is More : Can We Abandon Prophylactic Platelet Transfusion in Dengue Fever?, Annals Academy of Medicine 40 (12).

11. Chaterji S., et al, 2011, Evaluation of The NS1 Rapid Test and The WHO Dengue Classification Schemes for Use as Bedside Diagnosis of Acute Dengue Fever in Adults, The American Society of Tropical Medicine and Hygiene 84 (2) : 224228 . 